\title{
Evaluation of Coloured Sweet Pepper Genotypes under Temperate Conditions of Kashmir Valley
}

\author{
Amreena Sultan*, Baseerat Afroza, Mehraj-u-din Shah, Afroza Akhter, \\ Syed Azrah, Usmajan, Majid Rashid and Muzamil Rather
}

Division of Vegetable Science, Sher-e-Kashmir University of Agricultural Sciences and Technology of Kashmir, Shalimar, Srinagar- 190 025, Jammu and Kashmir (India)

*Corresponding author

\section{A B S T R A C T}

K e y w o r d s
Sweet pepper,
Evaluation,
Varieties

Introduction

Bell pepper (Capsicum annuum L. var. grossum Sendt.), also known as Sweet pepper, green pepper and Shimla mirch is grown worldwide for its delicate taste, pleasant flavor and colour and is also the most leading crop under protected structures. Sweet pepper consists of tall and stout plants with generally large sized fruits which are smooth, thick fleshed, inflated with depression at the base, sides usually furrowed, 3-4 lobed, broadly oblong, bell or apple shaped, generally green at immature stage and yellow or orange red or red when mature and non-pungent or mild in flavor. Some cultivars of the plant produce immature fruits in different colours, including red, yellow, orange, green, chocolate/brown, vanilla/white, and purple. It holds a very coveted position as leading off-season vegetable by generating cash revenues to the farmers by selling the produce in the neighbouring states and metropolitan cities.

The climatic conditions of Kashmir valley are ideal not only for the production of fruits but also for quality seed production which offers a great scope for production and export of quality seed to rest of the country. It is necessary to identify and develop varieties showing good performance under temperate environmental conditions of Kashmir. 


\section{Materials and Methods}

The present investigation was conducted during Kharif 2018 at Vegetable Experimental Farm, Sher-e-Kashmir University of Agricultural Sciences and Technology, Shalimar. The basic materials consisted of fifteen diverse genotypes of coloured capsicum (Capsicum annuиm L. var. grossum Sendt.). The experiment was laid out in a completely randomized block design with three replications. The observations were recorded on various maturity, yield attributing and quality traits. The data was analysed as per standard statistical procedures.

\section{Results and Discussion}

Mean performance of genotypes for maturity, yield and quality traits is presented in Table $1 \mathrm{a}$ and $1 \mathrm{~b}$. The perusal of table depicts the existence of sufficient amount of variation in the given set of genotypes there by indicating a good scope for improvement of the population through various breeding procedures. Table 2 reveals the best genotypes of based on per se performance with respect to different traits.

Data on average number of days taken for flowering revealed that SH-SP-5 was earliest taking 28.80 days for first flowering followed by SH-SP-2 (28.95 days) and SH-SP-11 (29.42 days). The average number of days to first flowering of all the genotypes was 31.31. Data on number of days taken to first fruit set revealed that SH-SP-11 (33.64 days) was earliest followed by SH-SP-5 (34.42) and SHSP-8 (34.85 days). The average number of days to first fruit set of all the genotypes was 36.68 days. Average number of days taken for first harvest was lowest in SH-SP-5 (49.02 days) followed by SH-SP-2 (50.40 days) and SH-SP-11 (50.49 days). The average number of days to first fruit harvest of all the genotypes was 52.48 days.
Highest plant height of $52.61 \mathrm{~cm}$ was observed in SH-SP-2 followed by SH-SP-8 $(51.28 \mathrm{~cm})$ and SH-SP-14 $(50.93 \mathrm{~cm})$. The average plant height of all the genotypes was $46.15 \mathrm{~cm}$. Maximum spread was observed in SH-SP-2 $(45.28 \mathrm{~cm})$ followed by SH-SP-8 $(45.151 \mathrm{~cm})$ and SH-SP-14 $(43.942 \mathrm{~cm})$. The average plant spread of all the genotypes was $41.55 \mathrm{~cm}$. Maximum number of secondary branches plant ${ }^{-1}$ (8.09) was recorded in the genotype SH-SP-5 which was followed by SH-SP-11 (7.88) and Nishat-1 (7.66). The average number of secondary branches plant ${ }^{-1}$ of all the genotypes was 7.34.

SH-SP-11 (13.79) followed by SH-SP-5 (13.64) and Nishat-1 (13.15) recorded maximum number of fruits per plant. The average number of fruits plant ${ }^{-1}$ of all the genotypes was 11.00.The genotypes SH-SP-2 $(106.05 \mathrm{~g})$ followed by SH-SP-3 (102.65 g) and SH-SP-8 (102.03 g) exhibited highest fruit weight as compared to Nishat-1 (77.16 g). The average of all the genotypes was $90.93 \mathrm{~g}$. Highest average fruit length of (7.47 $\mathrm{cm})$ was observed in SH-SP-1 followed by SH-SP-7 $(7.38 \mathrm{~cm})$ and SH-SP-2 $(7.35 \mathrm{~cm})$. The average fruit length of all the genotypes was $6.96 \mathrm{~cm}$.

Fruit diameter was found highest in the genotype SH-SP-1 $(7.29 \mathrm{~cm})$ followed by $\mathrm{SH}-$ SP-12 $(7.13 \mathrm{~cm})$ and SH-SP-4 $(7.00 \mathrm{~cm})$. The average fruit diameter of all the genotypes was $6.89 \mathrm{~cm}$. Maximum flesh thickness was recorded in the genotype SH-SP-1 (5.86 mm) followed by SH-SP-7 $(5.85 \mathrm{~mm})$ and SH-SP-3 $(5.83 \mathrm{~mm})$.

The average flesh thickness of all the genotypes was $5.29 \mathrm{~mm}$. The highest pedicel length was recorded in the genotype SH-SP-4 $(3.55 \mathrm{~cm})$ followed by SH-SP-2 $(3.45 \mathrm{~cm})$ and SH-SP-8 $(3.427 \mathrm{~cm})$. The average pedicel length of all the genotypes was $3.07 \mathrm{~cm}$. 
Table.1a Mean performance coloured capsicum (Capsicum annuиm L. var.grossum Sendt.) genotypes

\begin{tabular}{|c|c|c|c|c|c|c|c|c|c|c|c|c|c|}
\hline S.No. & Genotypes & $\begin{array}{l}\text { Days to } \\
\text { first } \\
\text { flowering }\end{array}$ & $\begin{array}{l}\text { Days to } \\
\text { first } \\
\text { fruit set }\end{array}$ & $\begin{array}{l}\text { Days to } \\
\text { first } \\
\text { harvest }\end{array}$ & $\begin{array}{l}\text { Plant } \\
\text { height } \\
(\mathrm{cm})\end{array}$ & $\begin{array}{l}\text { Plant } \\
\text { spread } \\
(\mathrm{cm})\end{array}$ & $\begin{array}{l}\text { Number } \\
\text { of } \\
\text { secondary } \\
\text { branches }\end{array}$ & $\begin{array}{c}\text { Number } \\
\text { of fruits } \\
\text { plant }^{-1}\end{array}$ & $\begin{array}{l}\text { Average } \\
\text { fruit } \\
\text { weight } \\
\text { (g) }\end{array}$ & $\begin{array}{l}\text { Fruit } \\
\text { length } \\
(\mathrm{cm})\end{array}$ & $\begin{array}{l}\text { Fruit } \\
\text { diameter } \\
(\mathbf{c m})\end{array}$ & $\begin{array}{l}\text { Flesh } \\
\text { thicknes } \\
\text { s (mm) }\end{array}$ & $\begin{array}{l}\text { Pedicel } \\
\text { length } \\
\text { (cm) }\end{array}$ \\
\hline 1. & SH-SP-1 & 31.11 & 37.82 & 52.29 & 47.57 & 42.24 & 7.53 & 10.75 & 94.77 & 7.47 & 7.29 & 5.86 & 3.26 \\
\hline 2. & SH-SP-2 & 28.95 & 35.73 & 50.40 & 52.601 & 45.28 & 7.42 & 11.73 & 106.05 & 7.35 & 6.92 & 4.99 & 3.45 \\
\hline 3. & SH-SP-3 & 32.53 & 37.44 & 53.67 & 41.00 & 40.91 & 6.91 & 11.47 & 102.65 & 6.97 & 6.94 & 5.83 & 2.47 \\
\hline 4. & SH-SP-4 & 30.67 & 36.31 & 51.64 & 45.06 & 41.58 & 7.53 & 11.47 & 83.71 & 6.84 & 7.00 & 4.63 & 3.55 \\
\hline 5. & SH-SP-5 & 28.80 & 34.42 & 49.02 & 49.02 & 40.57 & 8.09 & 13.64 & 84.09 & 6.73 & 6.74 & 4.91 & 2.96 \\
\hline 6. & SH-SP-7 & 30.80 & 37.27 & 52.87 & 47.30 & 41.11 & 7.33 & 10.18 & 92.32 & 7.38 & 7.21 & 5.85 & 3.24 \\
\hline 7. & SH-SP-8 & 29.47 & 34.85 & 51.55 & 51.28 & 45.15 & 7.38 & 10.98 & 102.09 & 7.31 & 6.83 & 4.50 & 3.48 \\
\hline 8. & SH-SP-9 & 33.02 & 37.49 & 53.31 & 40.32 & 41.12 & 7.00 & 9.85 & 101.32 & 6.87 & 6.83 & 5.82 & 2.45 \\
\hline 9. & SH-SP-10 & 31.11 & 35.87 & 52.38 & 44.45 & 41.51 & 7.62 & 10.33 & 80.84 & 6.74 & 6.94 & 5.16 & 3.19 \\
\hline 10. & SH-SP-11 & 29.42 & 33.64 & 50.49 & 47.86 & 40.70 & 7.89 & 13.78 & 78.27 & 6.63 & 6.66 & 4.85 & 2.95 \\
\hline 11. & SH-SP-12 & 32.82 & 38.82 & 53.89 & 45.97 & 39.83 & 7.00 & 9.75 & 89.33 & 7.16 & 7.13 & 5.78 & 3.23 \\
\hline 12. & SH-SP-14 & 31.44 & 37.33 & 53.00 & 50.93 & 43.94 & 6.93 & 10.18 & 98.72 & 7.13 & 6.75 & 4.95 & 3.43 \\
\hline 13. & SH-SP-15 & 34.82 & 39.07 & 55.53 & 38.99 & 40.19 & 6.64 & 8.75 & 94.79 & 6.74 & 6.72 & 5.79 & 2.44 \\
\hline 14. & SH-SP-16 & 33.47 & 38.02 & 53.98 & 43.05 & 40.24 & 7.18 & 9.44 & 77.86 & 6.57 & 6.86 & 5.19 & 3.17 \\
\hline \multirow[t]{2}{*}{15.} & Nishat-1 & 31.18 & 36.15 & 52.35 & 46.86 & 38.89 & 7.67 & 13.15 & 77.16 & 6.49 & 6.50 & 4.80 & 2.92 \\
\hline & CD at $5 \%$ & 1.487 & 1.227 & 1.690 & 3.989 & 2.287 & 0.737 & 2.084 & 20.812 & 0.445 & 0.353 & 0.617 & 0.285 \\
\hline
\end{tabular}


Table.1b Mean performance of coloured capsicum (Capsicum annuиm L. var.grossum Sendt.) genotypes

\begin{tabular}{|c|c|c|c|c|c|c|c|c|c|c|c|}
\hline S.No. & Genotypes & $\begin{array}{l}\text { Average } \\
\text { seed } \\
\text { weight } \\
\text { fruit }^{-1}(g)\end{array}$ & $\begin{array}{l}\text { Number } \\
\text { of seeds } \\
\text { fruit }^{-1}\end{array}$ & $\begin{array}{c}\text { Average } \\
\text { fruit yield } \\
\text { plant }^{-1} \\
\text { (kg) }\end{array}$ & $\begin{array}{l}\text { Average } \\
\text { fruit yield } \\
\text { plot }^{-1}(\mathrm{~kg})\end{array}$ & $\begin{array}{l}\text { Seed yield } \\
\text { plant }^{-1}(\mathrm{~g})\end{array}$ & $\begin{array}{c}\text { Seed yield } \\
\text { plot }^{-1}(g)\end{array}$ & $\begin{array}{c}\text { SSC } \\
\left({ }^{\circ} \text { Brix }\right)\end{array}$ & $\begin{array}{c}\text { Vitamin } \\
\mathrm{C} \\
(\mathrm{mg} / \mathbf{1 0 0 g})\end{array}$ & $\begin{array}{c}\text { Total } \\
\text { chlorophyll } \\
(\mathbf{m g} / \mathbf{1 0 0 g})\end{array}$ & $\begin{array}{c}\text { Total } \\
\text { carotenoids } \\
(\mathrm{mg} / 100 \mathrm{~g})\end{array}$ \\
\hline 1. & SH-SP-1 & 4.17 & 255.51 & 0.99 & 9.97 & 44.49 & 445.22 & 3.67 & 155.33 & 80.50 & 1.02 \\
\hline 2. & SH-SP-2 & 4.63 & 262.91 & 1.28 & 12.80 & 54.43 & 544.33 & 4.49 & 167.78 & 81.14 & 0.91 \\
\hline 3. & SH-SP-3 & 4.02 & 235.33 & 1.04 & 10.45 & 41.88 & 418.85 & 3.08 & 126.67 & 59.78 & 0.85 \\
\hline 4. & SH-SP-4 & 4.30 & 248.22 & 0.91 & 9.11 & 47.07 & 470.70 & 3.93 & 148.12 & 74.55 & 0.36 \\
\hline 5. & SH-SP-5 & 3.96 & 261.27 & 1.15 & 11.50 & 52.67 & 526.71 & 3.95 & 161.11 & 71.52 & 0.37 \\
\hline 6. & SH-SP-7 & 4.14 & 254.04 & 0.93 & 9.36 & 41.42 & 414.19 & 3.59 & 156.31 & 80.97 & 0.91 \\
\hline 7. & SH-SP-8 & 4.61 & 261.78 & 1.17 & 11.75 & 50.71 & 507.13 & 4.42 & 168.80 & 80.97 & 0.88 \\
\hline 8. & SH-SP-9 & 3.95 & 234.00 & 0.91 & 9.10 & 37.26 & 372.62 & 3.11 & 127.44 & 60.24 & 0.86 \\
\hline 9. & SH-SP-10 & 4.29 & 248.58 & 0.82 & 8.27 & 43.48 & 434.80 & 3.92 & 149.91 & 74.93 & 0.36 \\
\hline 10. & SH-SP-11 & 3.93 & 261.60 & 1.12 & 11.25 & 52.29 & 522.90 & 3.88 & 156.09 & 71.26 & 0.37 \\
\hline 11. & SH-SP-12 & 4.06 & 248.93 & 0.86 & 8.56 & 39.28 & 392.80 & 3.70 & 155.89 & 80.48 & 0.92 \\
\hline 12. & SH-SP-14 & 4.59 & 257.33 & 1.03 & 10.30 & 46.70 & 467.04 & 4.24 & 167.45 & 80.36 & 0.87 \\
\hline 13. & SH-SP-15 & 3.89 & 230.87 & 0.79 & 7.86 & 32.74 & 327.37 & 3.23 & 125.90 & 59.69 & 0.85 \\
\hline 14. & SH-SP-16 & 4.16 & 245.64 & 0.73 & 7.28 & 38.64 & 386.39 & 3.78 & 148.29 & 75.04 & 0.36 \\
\hline \multirow[t]{2}{*}{15.} & Nishat-1 & 3.87 & 256.87 & 1.02 & 10.25 & 49.03 & 490.29 & 4.09 & 160.72 & 72.11 & 0.37 \\
\hline & CD at $5 \%$ & 0.457 & 20.966 & 0.262 & 2.633 & 7.780 & 77.820 & 0.519 & 17.491 & 10.341 & 0.264 \\
\hline
\end{tabular}


Table.2 Best genotypes of coloured capsicum (Capsicum annuиm var. grossum Sendt.) based on per se performance with respect to different traits

\begin{tabular}{|c|c|c|}
\hline S.No & Traits & Best Genotypes \\
\hline 1. & Days to flowering & SH-SP-5 (28.80), SH-SP-2 (28.95 days) and SH-SP-11 (29.42 days). \\
\hline 2. & Days to first fruit set & SH-SP-11 (33.64 days), SH-SP-5 (34.42) and SH-SP-8 (34.85 days) \\
\hline 3. & $\begin{array}{l}\text { Days to first fruit } \\
\text { harvest }\end{array}$ & SH-SP-5 (49.02 days), SH-SP-2 (50.40 days) and SH-SP-11 (50.49 days) \\
\hline 4. & Plant height & SH-SP-2 $(52.61 \mathrm{~cm})$, SH-SP-8 $(51.28 \mathrm{~cm})$ and SH-SP-14 $(50.93 \mathrm{~cm})$. \\
\hline 5. & Plant spread & SH-SP-2 $(45.28 \mathrm{~cm})$, SH-SP-8 $(45.151 \mathrm{~cm})$ and SH-SP-14 $(43.942 \mathrm{~cm})$ \\
\hline 6. & $\begin{array}{l}\text { No. of secondary } \\
\text { branches plant }^{-1}\end{array}$ & SH-SP-5 (8.09), SH-SP-11 (7.88) and Nishat-1 (7.66). \\
\hline 7. & No. of fruits plant ${ }^{-1}$ & SH-SP-11 (13.79), SH-SP-5 (13.64) and Nishat-1 (13.15) \\
\hline 8. & Fruit weight & SH-SP-2 (106.05 g), SH-SP-3 (102.65 g) and SH-SP-8 (102.03 g) \\
\hline 9. & Fruit length & SH-SP-1 $(7.47 \mathrm{~cm})$, SH-SP-7 $(7.38 \mathrm{~cm})$ and SH-SP-2 $(7.35 \mathrm{~cm})$ \\
\hline 10. & Fruit diameter & SH-SP-1 $(7.29 \mathrm{~cm})$, SH-SP-12 $(7.13 \mathrm{~cm})$ and SH-SP-4 $(7.00 \mathrm{~cm})$ \\
\hline 11. & Flesh thickness & SH-SP-1 (5.86 mm), SH-SP-7 (5.85 mm) and SH-SP-3 (5.83 mm) \\
\hline 12. & Pedicel length & SH-SP-4 (3.55 cm), SH-SP-2 $(3.45 \mathrm{~cm})$ and SH-SP-8 $(3.427 \mathrm{~cm})$ \\
\hline 13. & Seed weight fruit ${ }^{-1}$ & SH-SP-2 (4.63 g), SH-SP-8 (4.61 g) and SH-SP-14 (4.586 g) \\
\hline 14. & Number of seeds fruit ${ }^{-1}$ & SH-SP-2 (262.91), SH-SP-8 (261.78) and SH-SP-5 (261.27) \\
\hline 15. & Fruit yield plant ${ }^{-1}$ & SH-SP-2 (1.28 kg), SH-SP-11 (1.12 kg) and SH-SP-5 (1.15 kg) \\
\hline 16. & Fruit yield plot ${ }^{-1}$ & SH-SP-2 (12.80 kg), SH-SP-8 (11.75 kg) and SH-SP-11 (11.25 kg) \\
\hline 17. & Seed yield plant ${ }^{-1}$ & SH-SP-2 (54.43 g), SH-SP-5 (52.67 g) and SH-SP-11 (52.290 g) \\
\hline 18. & Seed yield plot ${ }^{-1}$ & SH-SP-2 (544.33 g), SH-SP-5 (526.71 g) and SH-SP-11 (522.900 g) \\
\hline 19. & SSC & SH-SP-2 (4.49 ${ }^{\circ}$ brix $)$, SH-SP-8 (4.42 ${ }^{\circ}$ brix $)$ and SH-SP-14 (4.24 ${ }^{\circ}$ brix $)$ \\
\hline 20. & Vitamin C & $\begin{array}{l}\text { SH-SP-8 (168.80 mg/100g), SH-SP-2 (167.78 mg/100g) and SH-SP-14 (167.455 } \\
\mathrm{mg} / 100 \mathrm{~g})\end{array}$ \\
\hline 21. & Total chlorophyll & SH-SP-2 $(81.14 \mathrm{mg} / 100 \mathrm{~g})$, SH-SP-8 $(80.97 \mathrm{mg} / 100 \mathrm{~g})$ and SH-SP-7 $(80.97 \mathrm{mg} / 100 \mathrm{~g})$ \\
\hline 22. & Total carotenoid & SH-SP-1 $(1.02 \mathrm{mg} / 100 \mathrm{~g})$, SH-SP-12 $(0.92 \mathrm{mg} / 100 \mathrm{~g})$ and SH-SP-7 $(0.91 \mathrm{mg} / 100 \mathrm{~g})$ \\
\hline
\end{tabular}

The highest seed weight fruit ${ }^{-1}$ was found in SH-SP-2 (4.63 g) followed by SH-SP-8 (4.61 g) and SH-SP-14 (4.586 g). The average seed weight fruit ${ }^{-1}$ for all the genotypes was $4.17 \mathrm{~g}$. Highest number of seeds fruit ${ }^{-1}$ was found in the genotype SH-SP-2 (262.91) followed by SH-SP-8 (261.78) and SH-SP-5 (261.27). The average number of seeds fruit $^{-1}$ for all the genotypes was 250.86 .

Highest fruit yield plant ${ }^{-1}$ was recorded for the genotype SH-SP-2 (1.28 kg) followed by SHSP-11 (1.12 kg) and SH-SP-5 (1.15 kg). The average fruit yield plant ${ }^{-1}$ for all the genotypes was $0.98 \mathrm{~kg}$. The genotype SH-SP-2 (12.80 $\mathrm{kg}$ ) recorded the highest fruit yield plot $^{-1}$ followed by SH-SP-8 (11.75 kg) and SH-SP$11(11.25 \mathrm{~kg})$. The average fruit yield plot $^{-1}$ for all the genotypes was $9.85 \mathrm{~kg}$. Highest seed yield plant $^{-1}$ was recorded for the genotype SH-SP-2 (54.43 g) followed by SHSP-5 (52.67 g) and SH-SP-11 (52.290 g). The average seed yield plant ${ }^{-1}$ of all the genotypes was44.81 g. The genotype SH-SP-2 (544.33 g) recorded the highest seed yield plot $^{-1}$ followed by SH-SP-5 (526.71 g) and SH-SP$11(522.900 \mathrm{~g})$. The average seed yield plot $^{-1}$ of all the genotypes was $448.09 \mathrm{~g}$.

Highest SSC was recorded for the genotype SH-SP-2 (4.49 ${ }^{\circ}$ brix) followed by SH-SP-8 (4.42 ${ }^{\circ}$ brix), SH-SP-14 (4.24 ${ }^{\circ}$ brix) and Nishat-1 (4.088 ${ }^{\circ}$ brix). The average SSC of all the genotypes was $3.81{ }^{\circ}$ brix. The genotype SH-SP-8 (168.80 $\mathrm{mg} / 100 \mathrm{~g})$ recorded the highest vitamin $\mathrm{C}$ content followed by SH-SP-2 (167.78 mg/100g) and SH-SP-14 (167.455 mg/100g). The average 
vitamin $\mathrm{C}$ of all the genotypes was 151.72 $\mathrm{mg} / 100 \mathrm{~g}$.Highest total chlorophyll content was recorded for the genotype SH-SP-2 $(81.14 \mathrm{mg} / 100 \mathrm{~g})$ followed by SH-SP-8 (80.97 $\mathrm{mg} / 100 \mathrm{~g})$ and SH-SP-7 (80.97 mg/100g). The average total chlorophyll of all the genotypes was $73.57 \mathrm{mg} / 100 \mathrm{~g}$. The genotype SH-SP-1 $(1.02 \mathrm{mg} / 100 \mathrm{~g})$ recorded the highest total carotenoid content followed by SH-SP-12 $(0.92 \mathrm{mg} / 100 \mathrm{~g})$ and SH-SP-7 $(0.91 \mathrm{mg} / 100 \mathrm{~g})$. The average total carotenoid content of all the genotypes was $0.69 \mathrm{mg} / 100 \mathrm{~g}$. Table 2 depicts the best performing genotypes with respect to different traits.

Selection of genotypes on the basis of per se performance may be rewarding. However the per se performance should be supplemented with genetic studies like variability, heritability, genetic advance, correlation and path analysis, to make the process of selection more effective. Variation in performance of genotypes have also been reported by Stoffela et al., (1995) in Bell pepper for fruit size and marketable fruit yield; Srividhya and Ponnuswami (2010) in Paprika for number of fruits plant ${ }^{-1}$, fruit weight and fresh fruit yield plant $^{-1}$; Gurung et al., (2012) in Chilli for dry fruit weight plant $^{-1}$; Abu et al., (2013) in aromatic pepper for plant height, number of branches plant ${ }^{-1}$, number of fruits plant ${ }^{-1}$, fruit diameter, fruit length, pericarp thickness, single fruit weight and fresh fruit yield (t/ha); Tembhurne and Rao (2013) reported in Chilli for days to $50 \%$ flowering, number of fruits plant $^{-1}$, fruit length, fruit diameter, number of primary branches, plant height, number of seeds fruit ${ }^{-1}, 1000$ seed weight, fresh fruit weight plant $^{-1}$, net plot yield; Ummyiah et al., (2015) reported in tomato for plant height, days to first fruit picking, fruit length, fruit diameter, number of fruits plant $^{-1}$, average fruit weight, fruit yield plant ${ }^{-1}$ and fruit yield hectare-1;Zakiet al., (2015) in Sweet pepper for vitamin $\mathrm{C}$, total carotenoids, total sugars and Spaldonet al., (2017) in tomato for pericarp thickness, total soluble solids, ascorbic acid.

\section{References}

Abu, Ngozi.E.,Uguru, M.I. and Obi, I. U. 2013. Genotypic and correlation among quantitative characters in genotypes of aromatic pepper grown over years. African Journal of Biotechnology 12(20): 2792-2801.

Gurung, T., Suchila, T., Suriharn, B. and Sungcom, T. 2012. Stability analysis of yield and capsaicinoids content in chilli (Capsicum spp.) grown across six environments. Euphytica 187: 11-18.

Srividhya, S. and Ponnuswami. V. 2010. G × $E$ interaction and stability of yield in paprika genotypes (Capsicum annuumvar. longum) in Tamil Nadu. Electronic Journal of Plant Breeding 1(3): 297-300.

Spaldon. S., Samnotra, R.K., Rinchan, D. and Choudhary, D. 2017. Stability analysis and genotype $x$ environment interaction of quality traits in tomato (Solanum lycopersicum L.). Int.J. Curr. Microbiol. App.Sci. 6 (2): 1506-1515.

Stoffella, PJ., Locascio, S. J., Howe, T. K., Olson, S. M., Shuler, K.D., Vavrina, C. S. 1995. Yield and fruit size stability differ among bell pepper cultivars. Journal of the American Society for Horticultural Science1., 20: 325-328.

Tembhurne, B. V. and Rao, S. K. 2013. Stability analysis in chilli (Capsicum annumL.). Journal of Spices and Aromatic Crops 22(2): 154-164.

Ummyiah, H.M., Nayeema, J., Baseerat, A. and Faheema, M. 2015. Stability analysis and genotype $\times$ environment interaction of some tomato hybrids under Kashmir conditions. VEGETOS28(2): 36-40.

Zaki, N., Hakmaoui. A., Ouatmane. A., Pablo, J. 2013. Quality characteristics of 
Morccan sweet paprika (Capsicum annиum L.) at a different sampling

times. Food Sci. Technol. Campinas, 33(3): 577-585.

\section{How to cite this article:}

Amreena Sultan, Baseerat Afroza, Mehraj-u-din Shah, Afroza Akhter, Syed Azrah, Usmajan, Majid Rashid and Muzamil Rather. 2020. Evaluation of Coloured Sweet Pepper Genotypes under Temperate Conditions of Kashmir Valley. Int.J.Curr.Microbiol.App.Sci. 9(09): 23162322. doi: https://doi.org/10.20546/ijcmas.2020.909.289 